Урум Н.С., Шапіро Г.В, Максименко Л.А., Маларьова Н.О.

\title{
ДОСЛІДЖЕННЯ МОДЕЛІ ПРОЦЕСУ ЗГОРЯННЯ АЛЬТЕРНАТИВНИХ ВИДІВ ПАЛИВА В СУДНОВИХ ДИЗЕЛЯХ
}

Останнім часом усе більш широке поширення одержують альтернативні біопалива на основі рослинних олій (рапсових, соєвого, соняшникового, арахісового, пальмового) та їх похідних. Інтенсивні роботи з переведення дизелів на біопаливо ведуться як у краӥнах з обмеженим енергетичним потенціалом, так $і$ в краӥнах з великими запасами нафтового палива, а також у високорозвинених краӥнах, щчо мають фінансову можливість придбання нафтових енергоносіїв.

На даний час у Свропі (Німеччина, Франція, Австрія й ін. краӥни) щуорічно виробляється більш 1,5 млн. т біопалива. Це - сумімеве біопаливо, що містить до $10 \%$ складного метилового ефіру, який отримується з рапсової олії.

Аналіз ефективності виробничо-господарської діяльності підприємств водного транспорту свідчить, що середній рівень рентабельності їх основних послуг не високий. Отже, існує необхідність пошуку резервів підвищення ефективності перевезень і роботи транспортного флоту. Одним з напрямків наукового пошуку $\epsilon$ економічна очінка використання ресурсів $i$, насамперед, палива в компанії для досягнення корисного результату в діяльності. Проблема пошуку та оцінки ресурсозберігаючих технологій роботи транспортних судів є актуальною. Особливу гостроту їй додає ситуачія на ринку енергоносіїв за умови постійного коливання иін на паливо. Резерви для зменшення витрат на паливо полягають у нормуванні ходових операцій, вибору оптимальних режимів роботи двигунів на різних ділянках рейсу, вибору швидкості, щуо з одного боку забезпечить своєчасне виконання транспортної операції - а з іншого дозволить отримати економію у витраті палива. Дослідження полягає у можливості доведення отриманих теоретичних положень до практичних рекомендачій та безпосередньо пристроїв та обладнання, які дозволять використовувати альтернативні види палива з метою підвищення екологічних та енергетичних характеристик судових двигунів.

Ключові слова. паливо, двигуни, ресурсозберігаючі технології, дизельне паливо, транспортний флот

Постановка проблеми. Виробництво різних марок дизельного палива (ДП) 3 більш низькокиплячих фракцій нафти веде до зниження його цетанового числа (ЦЧ), а також до збільшення діапазону в'язкості палива, що у свою чергу впливає на роботу паливної апаратури. Однак ці палива краще 3 погляду вмісту сірки. 3 іншого боку, збільшення частки більш висококиплячих сортів нафти в загальному ії видобутку може привести до відповідного збільшення вмісту сірки, появі металів (таких як ванадій та ін.) й збільшенню змісту твердих часток і сажі у відпрацьованих газах (ВГ), що вплине на екологічність двигуна. Для двигунів великої розмірності (особливо суднових) негативним моментом стає зміна властивостей і підвищення концентрації шкідливих компонентів у залишкових нафтопродуктах.

Між перебудовою виробничих процесів у нафтопереробній промисловості, 3 одного боку, і обумовленими ними змінами в технічній політиці двигунобудівної промисловості маються численні взаємозв'язки, що вимагають створення єдиної концепції: вихідна сировина - паливо - двигун для отримання оптимального результату, 
якого, на жаль, поки не існує. У ряді робіт проблему використання палива в двигунах пропонується розглядати в рамках 4-елементної системи: двигун - паливо - мастило експлуатація. Раціональне використання палива може бути досягнуто наступними шляхами:

- за рахунок покращення якості палива з метою створення найбільш досконалого двигуна і підвищення ефективності його роботи;

- за рахунок модернізації двигуна 3 метою використання більш вигідних по вартості і ресурсам сортів палива;

- за рахунок одночасної зміни якості палива і модернізації двигуна.

Отже дослідження процесів згоряння альтернативних видів палива у судовому двигуні $є$ актуальним науково-технічним завданням.

Аналіз останніх досліджень і публікацій. Теоретичної базою дослідження $\epsilon$ роботи вітчизняних та закордонних авторів: Аникин С.А., Бажайкин А.Н., Бесчаров Е.Н., Вагнер В.А., Войнов А.Н., Гаврилов Б.Г., Гвоздев, Гладков О.А., Armstrong G., Thorp J. та багато інших [1-10].

Метою дослідження є підвищення екологічності та ефективності судових двигунів за рахунок використання альтернативних видів палива.

Основні результати дослідження. В економічній політиці всіх розвинених країн світу пріоритетним напрямком $є$ різке збільшення обсягу науково-дослідних і дослідноконструкторських робіт в галузі енергозбереження та екологічної безпеки, що станом на 2020 рік дозволяє створювати принципово нові двигуни та реалізувати ті наукові ідеї, які ще десять років тому вважалися практично фантастичними.

Значна частка виробленої у світі енергії (більш 30\%) споживається транспортом. 3 цих тридцяти відсотків переважна більшість (майже 95\%) приходиться на енергію, яка отримується при спалюванні нафтових палив.

Одним з основних споживачів рідкого вуглеводного палива $\epsilon$ водний транспорт, на якому дизелі є основним джерелом енергії. На судах морського та річкового флоту у дійсний час та на найближчу перспективу дизелі є основним джерелом енергії.

Показником енергетичної ефективності для суднової дизельної установки прийнято вважати питома ефективна витрата палива г/(квт.год)

Іншим не менш важливою вимогою, що у даний час пред'являються до суднових енергетичних установок - $є$ безумовне виконання Міжнародних екологічних норм. Більш того, ця вимога іноді ставиться на перше місце в переліку основних напрямках розвитку світового двигунобудування.

Перші Міжнародні норми, що обмежують викиди шкідливих (забруднюючих) речовин 3 газами суднових дизелів, що відробили, були прийняті 26 вересня 1997 року Міжнародної Морської Організації (IMO) на "Міжнародній Конвенції по запобіганню забруднення із судів" (МАРПОЛ 73/78). Цей директивний документ набрав сили 1 січня 2000 p. [64-1].

Складовою частиною Додатка VI МАРПОЛ 73/78, $є$ "Технічний Кодекс по викидах окислів азоту від суднових двигунів". У цьому документі нормуються питомі середньозважені викиди забруднюючих речовин, що утримуються в газах дизелів, що відробили.

У США охорону атмосферного повітря здійснює "Агентство по Захисту Навколишнього Середовища" (USEPA). У країнах СEC, для суднових дизелів річкового флоту, контроль за викидами шкідливих речовин в атмосферне повітря здійснює "Рейнська Комісія" (RCINC). Ця Комісія у свою чергу підкоряється "Свропейському Агентству Навколишнього Середовища" (EEA) [47]. Тут також слід зазначити, що норми забруднення, встановлені Агентством ЕЕА, також відповідають Міжнародному стандартові ISO 8178 "ДВЗ. Вимір емісії шкідливих речовин" [1].

32009 року набрав сили Європейський стандарт «Граничного Рівня Викидів для Європейських Водних Шляхів» (Stage III A). 
Минула в Лондоні з 6 по 10 жовтня 2008 р. 58 сесія Комітету з Захисту Морського Середовища (МЕРC) Міжнародної Морської Організації (IMO) прийняла нову редакцію "Правил Запобігання Забруднень із Судів", що корегують положення Додатка VI МАРПОЛ 73/78. Відповідно до прийнятого плану до 01 січня 2011 року введена чергова жорсткість кількості шкідливих викидів, що допускається, відповідно до міжнародних норм Tier 2.

У 2016 р. Правилами МАРПОЛ 73/78 у Зонах Контрольованих Викидів до яких відносяться Північноамериканське узбережжя Канади, США, Балтійське, Північне море і ряд районів Китайського узбережжя введені в дію норми Tier 3, що передбачають скорочення викидів оксидів азоту на 80 \% [2].

На рис. 1. представлена динаміка жорсткості норм шкідливих викидів судновими дизелями в новій редакції Додатка VI Матеріалів Міжнародної Конвенції МАРПОЛ $73 / 78$.

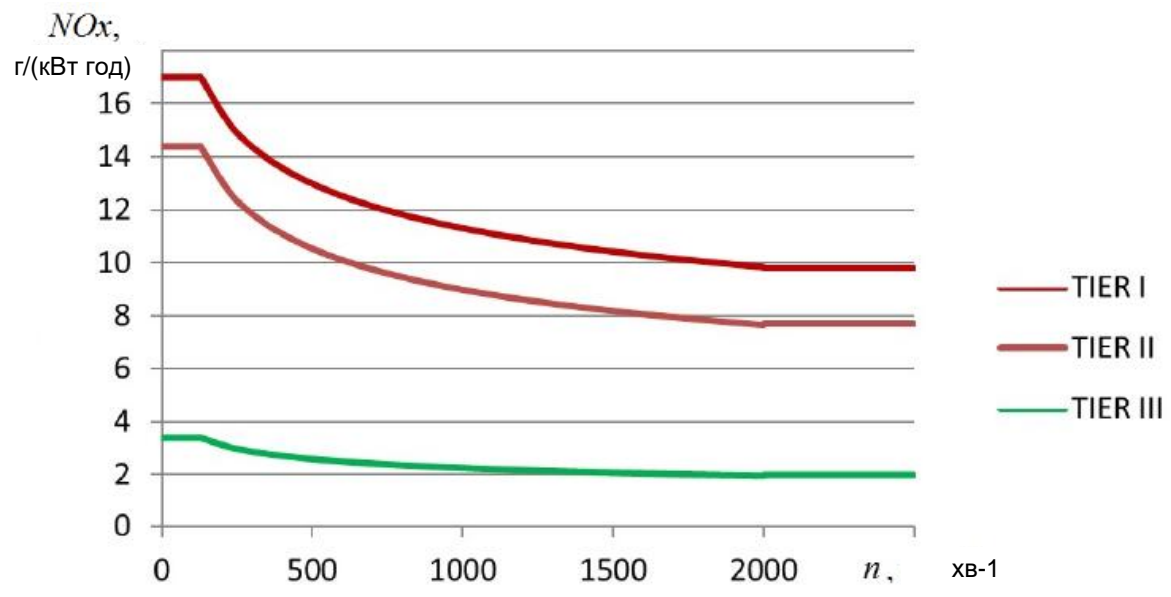

Рисунок 1 - Залежність граничних значень питомих середньозважених викидів оксидів азоту від частоти обертання колінчатого валу

Зменшення витрати палива двигуном лежить в сфері його енергоефективності. Показником енергетичної ефективності суднових дизельних енергетичних установок $\epsilon$ питома ефективна витрата палива.

Сучасні суднові ДВ3 відрізняе велика розмаїтість конструкцій та наявність додаткових механізмів, що у свою чергу збільшують механічні втрати і значно підвищують витрата палива. Для того, щоб при порівнянні енергетичної ефективності ці механічні втрати не враховувати в даному дослідженні будемо використовувати індикаторні показники.

Питома індикаторна витрата палива залежить тільки від якості здійснення робочого процесу і кількості теплових втрат. Робочий процес у дизелі, у загальному випадку, можна представити у виді окремих складових, які нерозривні, взаємозалежні та мають істотний взаємний вплив. До них відносяться процеси паливоподачі, сумішоутворення і згоряння.

Сучасна апаратура, яка подає паливо до транспортних дизелів є дуже складним i високотехнологічним обладнанням. У сучасних дизелях кількість вузлів і агрегатів, вироблених в Україні не перевищує 10-20 \%. При цьому частка імпортних комплектуючих збільшилася до 80-90 \%. До них у першу чергу до них відносяться апаратура для подачі палива, агрегати наддування і системи управління. Тому границі даних досліджень обмежимо тільки областю удосконалювання процесів сумішоутворення і згоряння.

Перші кроки в напрямку переведення морського транспорту на більш екологічні види палива світове співтовариство зробило в 2010 р., коли додатком VI МАРПОЛ 
73/78 IMO були встановлені особливі райони контролю викидів сірки - зони SECA (Sulfur Emission Control Areas). У цих зонах, куди на сьогоднішній день входять акваторії Північного і Балтійського морів, проливши Ла-Манш, Карибське море і 200мильні зони США і Канади, уведена заборона на використання високосернистого палива: 3 липня 2010 р. рівень вмісту сірки в паливі був обмежений $1 \%$, а 31 січня 2020 p. $-0,5 \%[3]$.

Однак ще до настання цього строку Міжнародна конвенція по запобіганню забруднення із судів посилила вимоги з вмісту сірки в судновому паливі до 0,1 \% по масі в зоні спеціального екологічного контролю SECA, ввівши в дію обмеження 31 січня 2015 року.

Розрізняють важкі та легкі суднові палива. Важкі: Residual Fuel; Intermediate Fuel Oil (IFO); флотський мазут марок Ф-5 і Ф-12. Легкі палива (дистиляти): Distillate Fuel, MDO (DMB) - дизельне паливо з вмістом сірки до 0,5-2,0 \% (Marine Diesel Oil); суднове малов'язке паливо.

До легких також відносять газомоторне паливо: MGO (DMA) - газойль, дизпаливо 3 вмістом сірки до 0,1\%, у діапазоні 0,1-0,5\% (Marine GasOil); зріджені вуглеводні гази. У виробництві палив категорії ULSFO, Ultra Low Sulfur Fuel Oil - RMD 80 (RMB $30)$ використовуються як легкі, так і важкі компоненти. Максимальний вміст сірки - 0,1 $\%[17]$.

Загальна витрата палива для бункерування морських судів (мазут, газойль, дизпаливо й інші низькосернисті дистиляти) складає близько 5,3 млн. барелей у добу. До 2021 р. загальний обсяг попиту на морське бункерне паливо досягне 5,8 млн барелей на добу [2-3].

Дослідимо особливості робочого процесу дизеля Ч 10,5/12 зі штатним і дослідним теплоізольованим профільованим поршнем при роботі на рослинній олії.

Для випробувань була використана доступна харчова соняшникова рослинна олія. Унаслідок підвищення щільності і в'язкості рослинної олії варто очікувати погіршення характеристик розпилювання. Порівняємо характеристики розпилювання, отримані для дизельного палива і рослинної олії. На рис. 2 приведені результати розрахунку сумарної, а на рис. 3. диференціальна характеристика розпилювання. На даних рисунках позначено: $\Omega$ - відношення об'єму краплі, що має діаметри від мінімального до даного до сумарного об'єму всіх крапель; $d \mathrm{k}$ - діаметр крапель, $d \Omega / d d \kappa$ - щільність розподілу імовірності краплі даного діаметра.

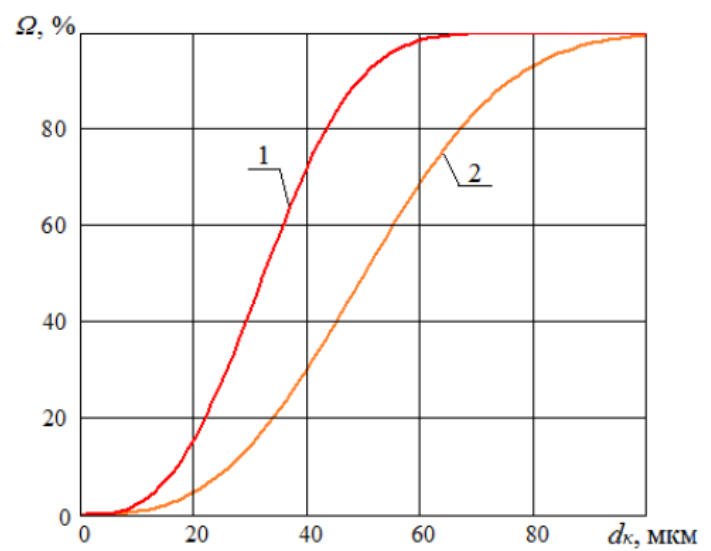

Рисунок 2 - Сумарна характеристика впорскування: 1 - дизельне паливо; 2 рослинна олія

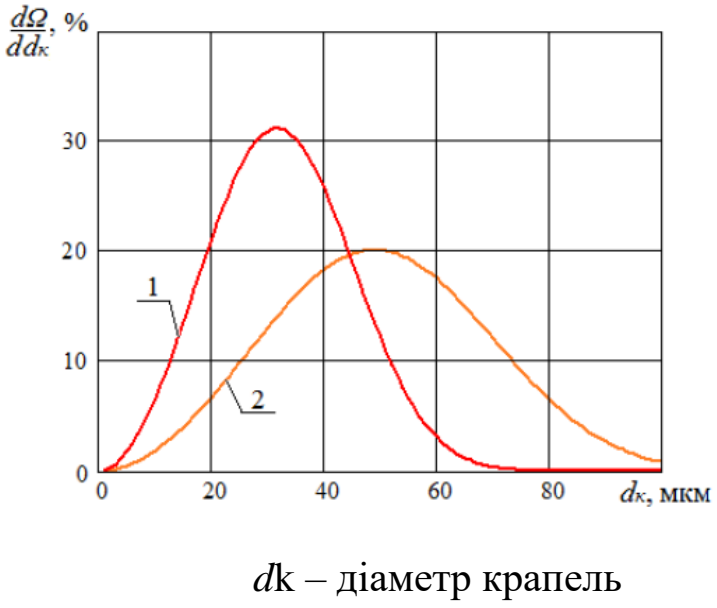

Рисунок 3 - Диференційна характеристика розпилювання: 1 - дизельне паливо, 2 - рослинна олія 
3 рис. 2 та 3 видно, що на рослинній олії розпилювання стає більш грубим, діаметр крапель збільшився більш ніж у 1,5 рази. Значить і період дифузійного горіння розпиленої рослинної олії повинен збільшитися.

Це підтверджується результатами випробувань.

На рис. 4 приведені результати порівняльних випробувань дизеля зі штатним поршнем при роботі на дизельному паливі і рослинній олії. 3 рис. 4 видно, що при переведенні з дизельного палива на рослинну олію спостерігається збільшення питомої індикаторної витрати палива на 13-15 \%, концентрації монооксиду вуглецю на 21-37 \%, і сумарних вуглеводнів на $8-12 \%$.

Температура ВГ збільшилася на 5-7 градусів. Вміст оксидів азоту зменшилося на 350-450 ppm. Димність ВГ знизилася незначно (у межах помилки виміру приладу).

Збільшення питомої індикаторної витрати палива пояснюється тим, що рослинна олія має меншу теплоту згоряння, ніж дизельне паливо.
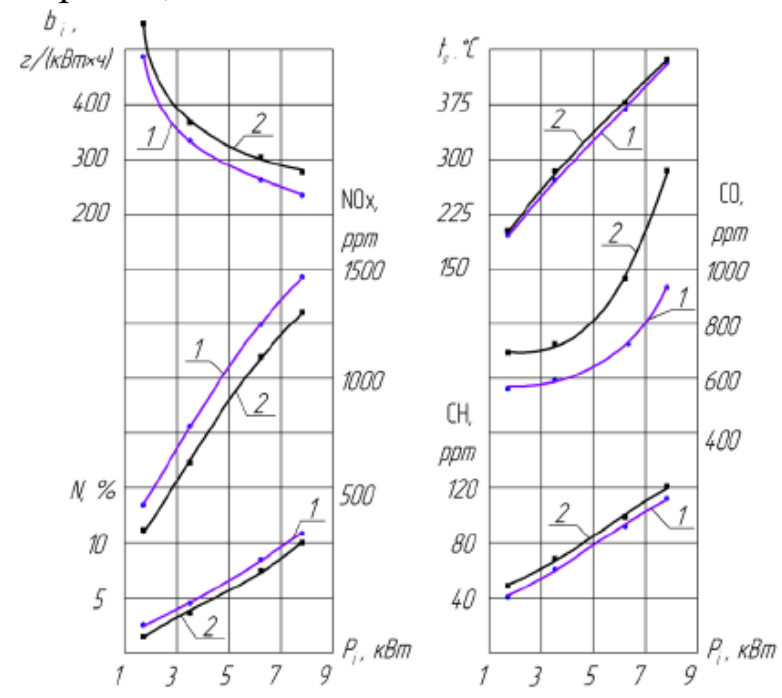

Рисунок 4 - Навантажувальні характеристики дизеля Ч 10,5/12 зі штатним поршнем при роботі на дизельному паливі і соняшниковій олії: 1 - дизельне паливо; 2 рослинна олія

Збільшення температури ВГ концентрації монооксида вуглецю i сумарних вуглеводнів пояснюється затягуванням процесу згоряння на лінію розширення. Це відбувається внаслідок збільшення періоду затримки запалення та погіршення характеристик розпилювання рослинної олії в порівнянні з дизельним дисятирічним паливом.

Тривалість періоду затримки запалення збільшилася в зв'язку з підвищенням температури спалаху рослинної олії на 157 градусів. Час горіння більш великих крапель збільшується, і період дифузійного горіння буде більше. Це підтверджується результатами розрахунків, приведених на малюнках 3.2 та 3.3.

Зменшення концентрації оксидів азоту - зниженням локальних градієнтів температур в об'ємі камері згоряння.

На рис. 3.5 приведені індикаторні діаграми, отримані при роботі на дизельному паливі та рослинній олії. 3 рис. 3.5 видно, що при перекладі двигуна 3 дизельного дистилятного палива на рослинну олію тривалість періоду затримки запалення збільшилася, а максимальний тиск згоряння зменшилося на 4,5 Мпа.

На рис. 3.6 приведені характеристики тепловиділення відсіку при роботі на різних паливах. 


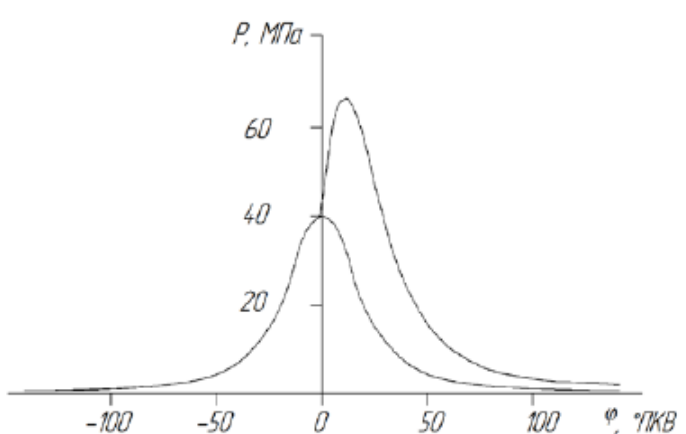

a)

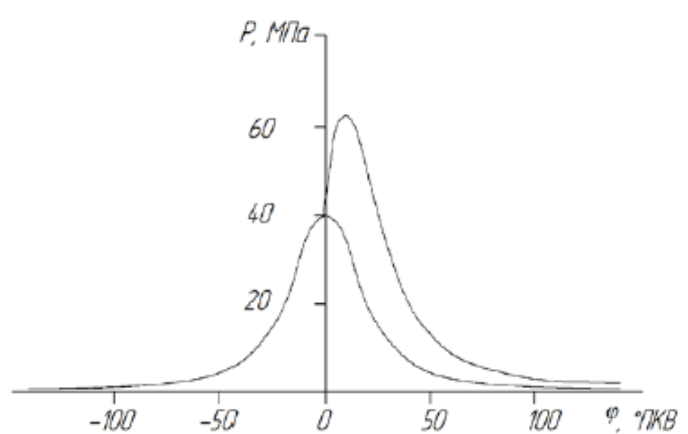

б)

Рисунок 5 - Індикаторні діаграми при роботі на різних паливах:

а) дизельне паливо; б) соняшникова олія

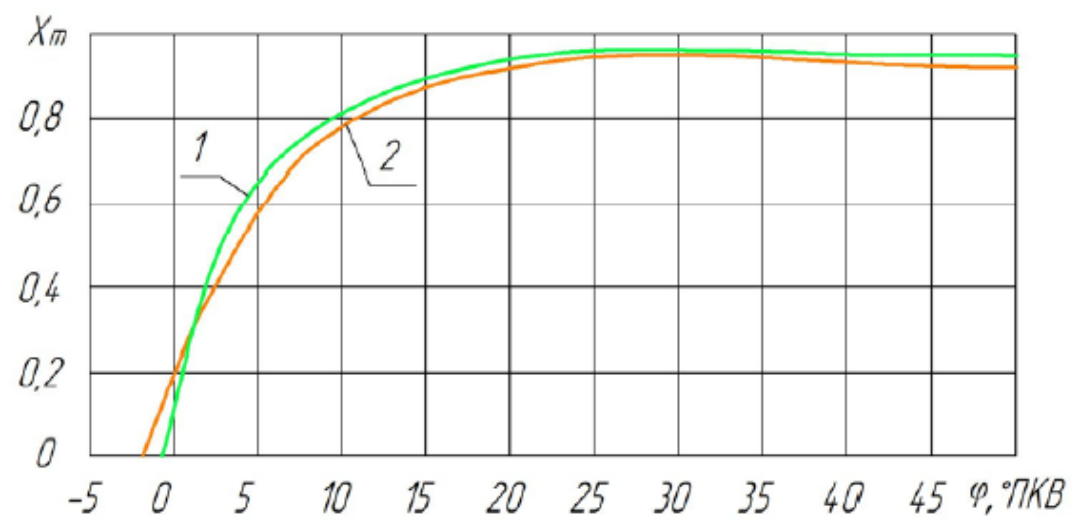

Рисунок 6 - Характеристики тепловиділення дизеля Ч 10,5/12 зі штатним поршнем при роботі на дизельному паливі і рослинній олії:

1 - дизельне паливо; 2 - рослинна олія

3 рис. 6 видно, що при роботі на рослинній олії (у порівнянні 3 дизельним паливом), інтенсивність тепловиділення знизилася, і процес згоряння змістився на лінію розширення. У результаті температура ВГ збільшилася.

Проведемо чисельні дослідження процесу обдуву зважених у пульсуючому повітряному середовищі крапель дизельного палива і рослинної олії, розміри яких приведені на рис. 7 та 8.

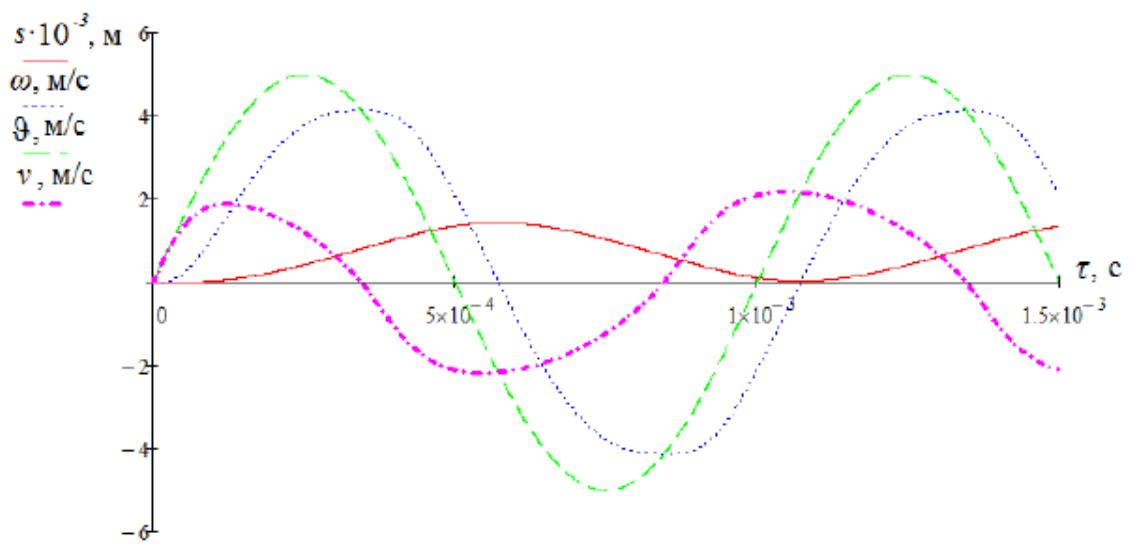

Рисунок 7 - Динаміка переміщення краплі дизельного палива діаметром 32 мкм в осцилюючому повітряному середовищі 


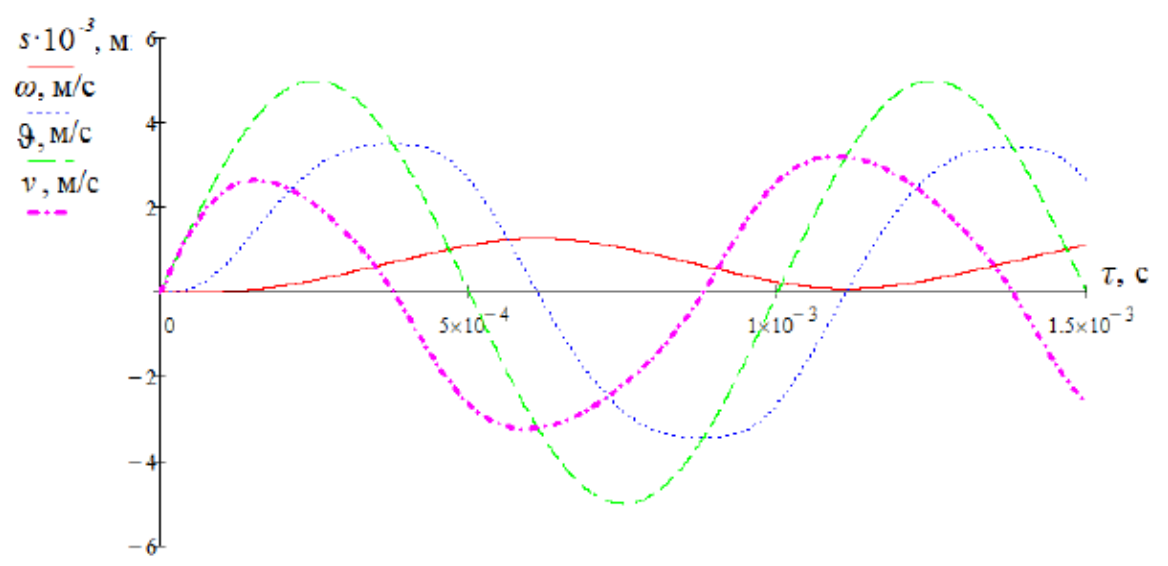

Рисунок 8 - Динаміка переміщення краплі рослинної олії діаметром 50 мкм в осцилюючому повітряному середовищі

На рисунках.7, 8 позначено:

- переміщення краплі щодо нейтральної осі; S

- швидкість руху краплі палива; $\omega$

- швидкість руху газового середовища; $\vartheta$

- швидкість обдува краплі палива. $v=9-\omega$.

3 приведених графіків видно, що для великих крапель рослинної олії процес обдуву їх газовим середовищем стає більш інтенсивним (у порівнянні 3 дрібними краплями дизельного палива). Отже, ефект від використання пульсацій газового середовища для скорочення періоду дифузійного згоряння на рослинній олії буде більш діючим.

Досліджуємо робочий процес дизеля Ч 10,5/12 на штатному і дослідному теплоізоляційному поршні з профільованою верхньою поверхнею при використанні як паливо рослинної олії.

На рис. 9 наведені результати порівняльних випробувань дизеля на рослинній олії зі штатним і експериментальним поршнем, що має теплоізольовану, профільовану камеру згоряння.
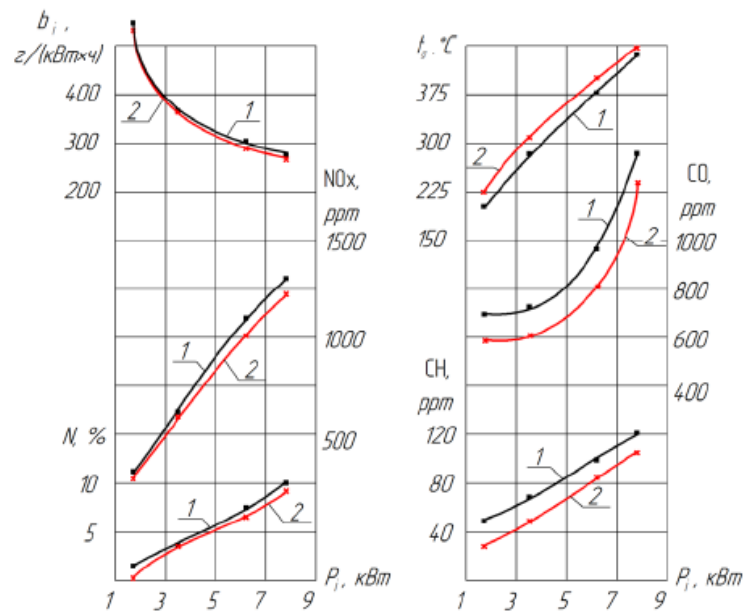

Рисунок .9 - Навантажувальні характеристики дизеля Ч 10,5/12 при частоті обертання колінчатого вала $1500 \mathrm{xB}^{-1}$, при роботі на рослинній олії:

1 - штатний поршень; 2 - теплоізольований поршень із профільованою верхньою поверхнею 
3 рис. 9 видно, що при роботі на рослинній олії використання теплоізольованого профільованого поршня, який генерує у камері згоряння газодинамічні коливання, у порівнянні зі штатним поршнем, покращило економічні та енергетичні характеристики дизеля. Зменшилася витрата палива, викиди газоподібних шкідливих речовин i димність ВГ.

До недоліків дослідницької камери згоряння варто віднести збільшення температури ВГ внаслідок додаткового підігріву повітряного заряду від теплоізольованих стінок камери згоряння.

На рис. 10 наведені індикаторні діаграми тиску газів у циліндрі дизеля зі штатним та теплоізольованим профільованим поршнем при роботі на соняшниковій олії.

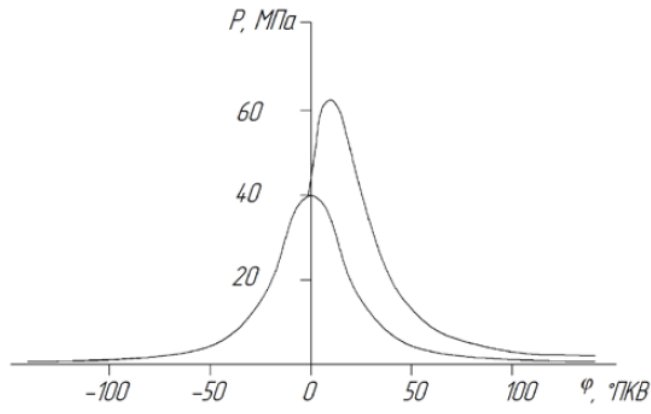

a)

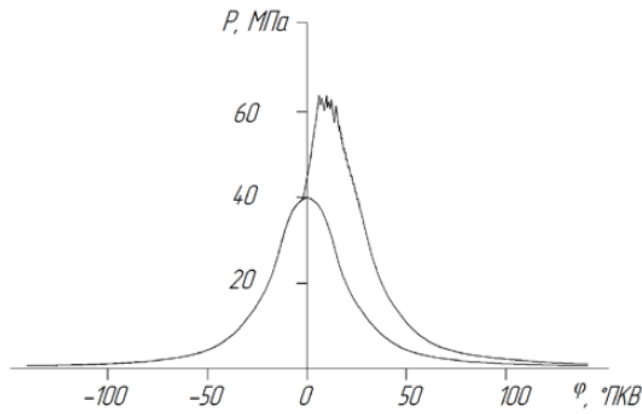

б)

Рисунок 10 - Індикаторні діаграми при роботі на рослинній олії:

а) - штатний поршень б) - теплоізольований поршень із профільованою верхньою поверхнею

3 наведеного рисунка видно, що на дослідницькому теплоізольованому поршні 3 профільованою верхньою поверхнею, у порівнянні зі штатним поршнем, спостерігаються інтенсивні коливання тиску газу в камері згоряння.

Горіння палива починається раніш на 3 градуси ПКВ через додатковий підігрів повітряного заряду від стінок камери згоряння. Значення максимального тиску згоряння практично не відрізняються, отже, навантаження на деталі ЦПГ не збільшиться. роботи.

На рис. 11 наведені характеристики тепловиділення для номінального режиму

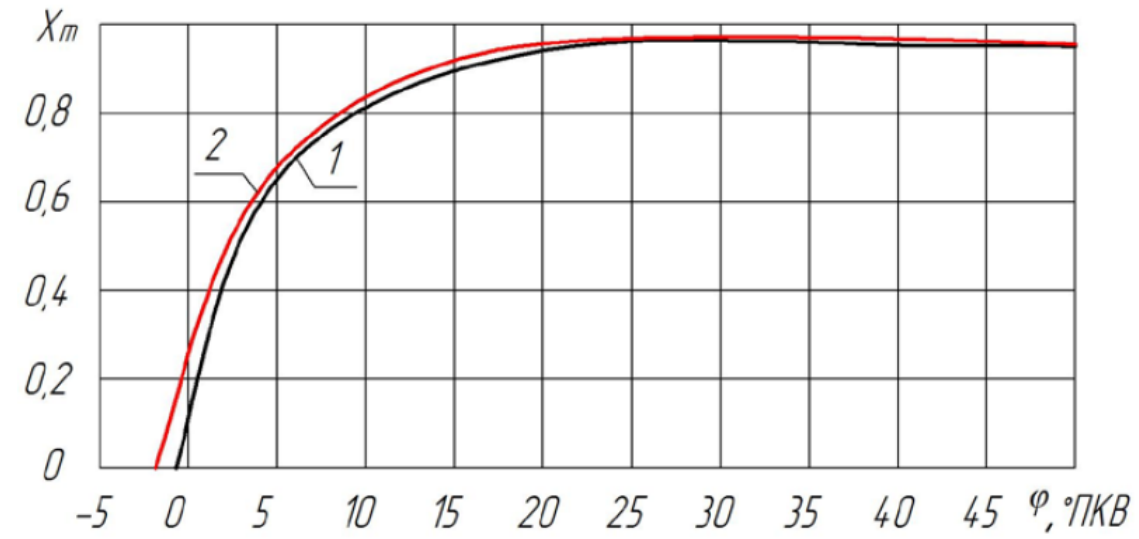

Рисунок 11 - Характеристики тепловиділення дизеля Ч 10,5/12 при роботі на рослинній олії: 1 - штатний поршень; 2 - теплоізольований профільований поршень 
Порівняльний аналіз характеристик тепловиділення, зображених на рис. 11, підтверджує позитивний вплив пульсацій газового середовища на інтенсифікацію процесу згоряння розпиленого палива і скорочення періоду дифузійного горіння.

Висновки: Використання на транспорті різних альтернативних палив забезпечує рішення проблеми заміщення нафтових палив, значно розширить сировинну базу для одержання моторних палив, полегшить рішення питань постачання паливом транспортних засобів і стаціонарних установок. Можливість одержання альтернативних палив 3 необхідними фізико-хімічними властивостями дозволить цілеспрямовано удосконалювати робочі процеси дизелів i, тим самим, покращити їх екологічні та економічні показники. При цьому особливу значимість мають альтернативні палива 3 поновлюваних джерел енергії (рослинні олії, відходи сільськогосподарського виробництва i харчової промисловості, біомаса), що дозволяють вирішити проблему зниження викидів в атмосферу вуглекислого газу. При переведенні дизеля зі штатним поршнем з дизельного палива на рослинну олію, питома індикаторна витрати палива збільшилася на 13-15 \%, концентрація монооксиду вуглецю на 21-37 \%, і сумарних вуглеводнів на 8-12\%. Температура ВГ, збільшилася на 5 градусів. Вміст оксидів азоту зменшився на 350-450 ppm. Димність ВГ залишилася на колишньому рівні. При переведенні дизеля зі штатного поршня на теплоізольований поршень із профільованою верхньою частиною, питома індикаторна витрата рослинної олії зменшився на 5-7 г/(квт.год), концентрація оксидів азоту на 85 ppm, монооксида вуглецю $140 \mathrm{ppm}$, сумарних вуглеводнів $20 \mathrm{ppm}$ та димність $1 \%$ по шкалі Hartrige. Температура ВГ збільшилася на 10-15 градусів.

\section{ЛIТЕРАТУРА}

1. Аникин С.А. Перспективы использования продуктов термохимической конверсии углеводородных топлив в транспортных ДВС / С.А. Аникин, Н.А. Иващенко, Ю.А. Маслов, В.М. Фомин, и др. // Двигатель 97 : материалы междунар. науч.-техн. конф. - М.: МГТУ, 1997. - С. $114-115$.

2. Бажайкин А.Н. Характеристика воспламенения и горения топливной струи в теплоизолированных камерах сгорания / А.Н. Бажайкин // Двигателестроение, 1992. - № 1-3. C. 7-9.

3. Бесчаров Е.Н. К вопросу о влиянии движения воздуха в цилиндре на индикаторный процесс четырехтактного двигателя / Е.Н. Бесчаров // Двигатель внутреннего сгорания: сб. науч. тр. / Харьковский государственный университет. - Харьков: Издательство Харьковского ордена Трудового Красного Знамени государственного университета имени А.М. Горького, 1967. - Вып. 5. - С. 3-8.

4. Вагнер В.А. Улучшение показателей дизеля путем добавки в топливо диметилового эфира / В.А. Вагнер, А.М. Гвоздев // Ползуновский вестник. Барнаул, 2006. - № 4. - С. 32-39.

5. Войнов А.Н. Сгорание в быстроходных поршневых двигателях / А.Н. Войнов. М.: Машиностроение, 1977. - 277 с.

6. Гаврилов Б.Г. Химические основы термофорсирования двигателя дизеля / Б.Г. Гаврилов, Е.И. Гулин, А.П. Лесников, Т.А. Новикова // Журнал прикладной химии. - 1963. - Т. 36. - Вып. 22. - С. 36-42.

7. Гвоздев А.М. Улучшение экологических показателей дизеля путем добавки в топливо диметилового эфира / А.М. Гвоздев, В.А. Вагнер. - Барнаул: Ползуновский вестник, 2006. - №4. - С. 33-38.

8. Гладков О.А. Создание малотоксичных дизелей речных судов / О.А. Гладков, Е.Ю. Лерман. - Л.: Судостроение, 1990. - 112 с. 
9. Грехов Л.В. Аккумуляторные топливные системы двигателей внутреннего сгорания Common Rail: учеб. пособие / Л.В. Грехов. - М.: Московский государственный технический университет имени Н. Э. Баумана, 2000. - 64 с.

10. Грехов Л.В. Топливная аппаратура и системы управления дизелей / Л.В. Грехов, Н.А. Иващенко, В.А. Марков. - М.: Легион-Автодата, 2005. - 344 с.

11. Егоров В.Г. Результаты теплотехнических испытаний дизеля $Г$ 70-5 на водотопливной эмульсии / В.Г. Егоров, В.Д. Сисин, В.С. Шабалин, Б.О. Лебедев // Сб. Совершенствование технической эксплуатации СЭУ и исследование процессов в судовых дизелях. - Новосибирск: Изд-во НИИВТ, 2016. - С. 25-26.

12. Жуков В.А. Экологические нормативы для транспортных дизелей и методы их обеспечения / В.А. Жуков, М.С. Курин // Справочник. Инженерный журнал М.: Машиностроение, 2017. - № 3. - С 33-36.

13. Калашников С.А. Альтернативные топлива для судовых дизельных энергетических установок / С.А. Калашников, А.Г. Николаев // Новосибирск: Новосиб. гос. акад. водн. трансп., 2011. - 90 с.

14. Коньков А.Ю. Моделирование процессов сгорания в тепловозных дизелях при диагностике / А.Ю. Коньков, А.А. Маркелов // Современные технологии железнодорожному транспорту и промышленности: Труды 43-й Всероссийской научно-практической конференции. - Хабаровск: Изд-во ДВГУПС, 2013. - Т. 1. C. $16-22$.

15. Armstrong G. Oil water emulsions as fuel / G. Armstrong, P. Katsoulakos // Mot. Ship. - 2020. - Vol. 60, № 716, P. 37-37.

16. Thompson R.V. The Burning of Emulsified Fuel in Diesel Engines / R.V. Thompson, J. Thorp, G. Armstrong, P. Katsoulakos // Trans. Inst. Mar. Eng. - № 10. - 2011. - P. $19-25$.

17. Thorp J. Running diesel on water / J. Thorp, G. Armstrong, P. Kasoulakos // Mar. Week Febr. - 2010. - Vol. 18, № 20. - P. 54-60.

Урум Н.С., Максименко Л.А. Маларьова Н. О., Шапиро Г.В. ИССЛЕДОВАНИЕ МОДЕЛИ ПРОЦЕССА СГОРАНИЯ АЛЬТЕРНАТИВНЫХ ВИДОВ ТОПЛИВА В СУДОВЫХ ДИЗЕЛЯХМ

В последнее время все более широкое распространение получают альтернативные биотоплива на основе растительных масел (рапсовое, соевого, подсолнечного, арахисового, пальмового) и их производных. Интенсивные работы по переводу дизелей на биотопливо ведутся как в странах с ограниченным энергетическим потенциалом, так и в странах с большими запасами нефтяного топлива, а также в высокоразвитых странах, имеющих финансовую возможность приобретения нефтяных энергоносителей.

В настоящее время в Европе (Германия, Франция, Австрия и др. Страны) ежегодно производится более 1500000 . Т биотоплива. Это - смесевое биотопливо, содержащее до $10 \%$ сложного метилового эфира, получаемого из рапсового масла.

Анализ производственно-хозяйственной деятельности предприятий водного транспорта свидетельствует, что средний уровень рентабельности их основных услуг не высок. Следовательно, существует необходимость поиска резервов повышения эффективности перевозок и работы транспортного флота. Одним из направлений научного поиска является экономическая оценка использования ресурсов и, прежде всего, топлива в компании для достижения полезного результата в деятельности. Проблема поиска и оценки ресурсосберегающих технологий работы транспортных судов является актуальной. Острые дискуссии ей придает ситуация на рынке энергоносителей при условии постоянного колебания цен на топливо. Резервы для уменьшения расходов на топливо состоят в нормировании ходовых операций, выбора оптимальных режимов работы двигателей на различных участках рейса, выбора 
скорости, с одной стороны обеспечит своевременное выполнение транспортной операции - а с другой позволит получить экономию в расходе топлива. Исследования заключается в возможности доведения полученных теоретических положений к практическим рекомендациям и непосредственно устройств и оборудования, которые позволят использовать альтернативные виды топлива с целью повышения экологических и энергетических характеристик судовых двигателей.

Ключевые слова: топливо, двигатели, ресурсосберегающие технологии, дизельное топливо, транспортный флот

\section{Urum N.S., Shapiro G.V., Maksimenko L.A. Malarova N.O. STUDY OF THE MODEL OF THE COMBUSTION OF ALTERNATIVE FUELS IN SHIP DIESELS}

Recently, alternative biofuels based on vegetable oils (rapeseed, soybean, sunflower, peanut, palm) and their derivatives are becoming more widespread. Intensive work on the conversion of diesel to biofuel is carried out both in countries with limited energy potential and in countries with large reserves of petroleum fuels, as well as in highly developed countries that have the financial capacity to purchase petroleum energy.

At present, more than 1.5 million tons of biofuels are produced annually in Europe (Germany, France, Austria, and other countries). It is a blended biofuel containing up to 10\% methyl ester derived from rapeseed oil.

Analysis of the efficiency of production and economic activities of water transport enterprises shows that the average level of profitability of their basic services is not high. Therefore, there is a need to find reserves to improve the efficiency of transportation and the work of the transport fleet. One of the areas of scientific research is the economic evaluation of the use of resources and, above all, fuel in the company to achieve a useful result in the activity. The problem of finding and evaluating resource-saving technologies of transport vessels is relevant. The situation on the energy market is especially acute given the constant fluctuations in fuel prices. Reserves for reducing fuel costs are the rationing of running operations, the choice of optimal modes of operation of engines on different sections of the flight, the choice of speed, which on the one hand will ensure timely transport operations and on the other allow fuel savings. The research consists in the possibility of bringing the obtained theoretical provisions to practical recommendations and directly to devices and equipment that will allow the use of alternative fuels in order to improve the environmental and energy performance of marine engines.

Keywords: fuel, engines, resource-saving technologies, diesel fuel, transport fleet 